\title{
Federal Open Market Committee Decisions in 1969-Year of Monetary Restraint
}

\author{
by ALBERT E. BURGER and CHARLOTTE E. RUEBLING
}

\begin{abstract}
MI
ONETARY ACTIONS IN 1969 exerted a decidedly more restrictive effect on the future course of economic activity than in the previous two years. All of the major economic variables generally used as indicators of monetary ease or restraint evidenced the restrictive influence. In 1969 the growth rates of the money stock, defined as currency and demand deposits held by the nonbank public, and money more broadly defined to include time deposits, decreased markedly from the previous two years. Bank credit likewise showed a slower rate of increase. Interest rates rose rapidly during most of the year, reaching levels well above their averages in previous years.
\end{abstract}

This article discusses the decisions of the Federal Open Market Committee (FOMC) in 1969 and the implementation of these policy decisions. It analyzes the contribution of FOMC policy actions to the reduction in the expansionary effect of monetary influences on the future growth of real economic activity and prices.

The FOMC is composed of the seven members of the Board of Governors of the Federal Reserve System and five of the twelve district Federal Reserve Bank presidents. The other seven presidents attend

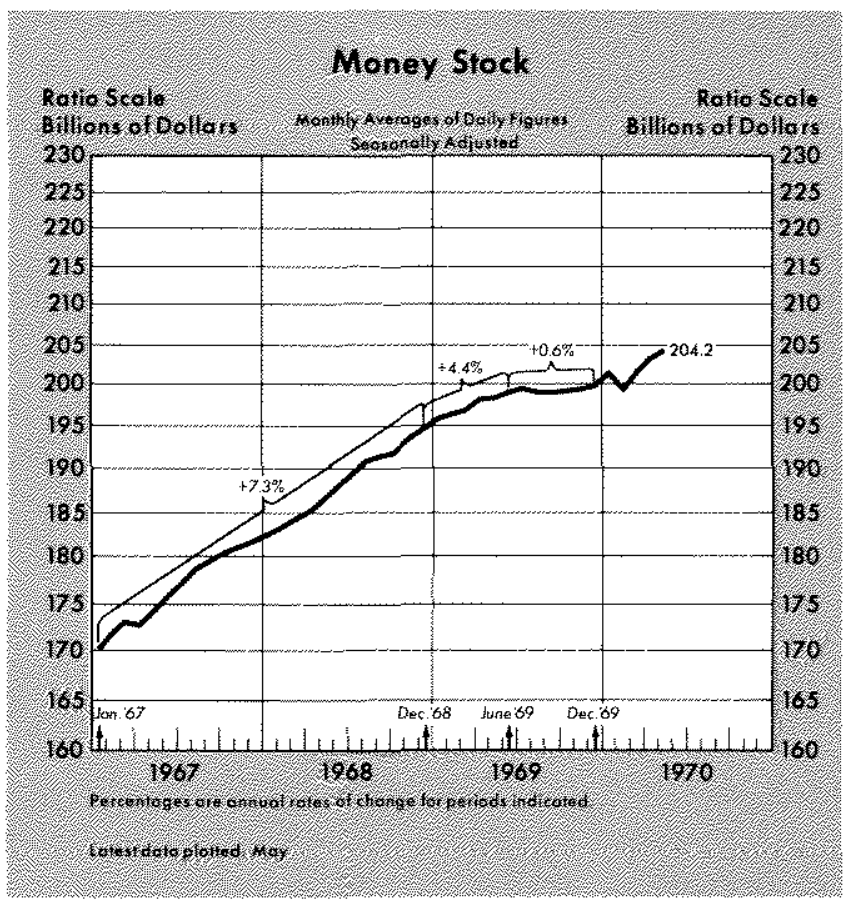

meetings and participate in the deliberations but do not vote. Except for the president of the New York Federal Reserve Bank who is a permanent member, membership rotates among the presidents each March. At the first two meetings of 1969 , the presidents on the FOMC, in addition to Mr. Hayes (New York), were: Mr. Kimbrel (Atlanta), Mr. Morris (Boston), Mr. Hickman (Cleveland), and Mr. Galusha (Mimneapolis). Beginning March 4, the rotating members were: Mr. Scanlon (Chicago), Mr. Coldwell (Dallas), Mr. Clay (Kansas City), and Mr. Bopp (Philadelphia).

The FOMC met fourteen times in 1969 to review and evaluate developments in the economy and, in light of these prevailing circumstances, to prescribe what objectives open market operations should try to achieve until the next meeting in order to further the longer-run goals of monetary policy. The matters discussed included: changes in spending, production, and prices; international developments; Treasury financing and the Federal budget; interest rates and other measures of money market conditions; and monetary aggregates. A summary of these diseussions including the text of the policy directive issued to the Federal Reserve Bank of New York - the Bank selected by the Committee to execute transactions for the System Open Market Account - is released to the public about 90 days after each meeting, and published in the Federal Reserve Bulletin and each spring in the Annual Report of the Board of Governors of the Federal Reserve System. The records of the meetings include the voting position of members and any dissenting comments.

\section{FOMC Directives}

After the majority of the membership of the FOMC has decided upon the desired infuence of monetary policy on ultimate targets (objectives of policy) such as employment and prices, the Committee issues a policy directive to the New York Federal Reserve Bank. The Trading Desk at the New York Bank carries out day-to-day open market transactions for the System. Hereafter, for sake of brevity, this article will refer to the directive as being issued to the "Desk."

It might appear that writing the directive would be a simple procedure. However, in actual operation 
this has not been the case. The infuence of FOMC policy actions on the ultimate targets of monetary policy is modified by many other economic factors. Therefore, the FOMC attempts to control one or more economic variables intermediate in the linkage between its purchase and sale of securities and real income, employment, and prices. Such intermediate variables may then be used to help indicate whether the total influence of the financial sector on future economic activity is becoming more or less expansionary.

There has been a lack of general agreement among the members of the FOMC as to which economic variable or variables best summarize the total influence of the financial sector on real economic activity. Some members believe that market interest rates are the best indicator. Others consider bank credit of major significance. A third viewpoint is that the money stock is the best indicator. Probably the predominate view is that all of these indicators and many other factors with changing weights should be considered.

During 1969 the directive to the Desk was worded in terms of "money and short-term credit market conditions." The majority of the FOMC deemed that these variables represented the best operational mechanism for implementing open market policy. For example, referring to Exhibit I, the operating instructions to the Desk in 1969 were repeatedly:

System open market operations until the next meeting of the Committee shall be conducted with a view to maintaining the prevailing firm conditions in money and short-tem credit markets.

Since May 10, 1966 the directive has also contained a "proviso clause" which instructs the Desk to alter its operations if a significant deviation in the economic variable stated in this clause is observed. In 1969 the proviso clause was stated in terms of bank credit. ${ }^{1}$

\footnotetext{
In recent years the Committee has been making use of daily-average statistics on total member bank deposits as a "bank credit proxy" - that is, as the best available measure, although indirect, of developing movements in bank credit. Because they can be compiled on a daily basis with a very short lag, the deposit figures are more nearly current than avatable bank loan and investment data. Moreover, average deposit figures for a calendar month are much less subject to the influence of single date fluctuations than are the available month-end data on total bank credit, which represent estimates of loans and investments at all commercial banks on one day - the last Wednesday - of each month.

Movements in total member bank deposits and in commercial bank credit can diverge for various reasons, including changes in nondeposit liabilities of banks. Because changes in U.S. bank liabilities to foreign branches recently have been an important source of divergence from time to time, an "adjusted" proxy series, taking approximate account of such changes, is now also being calculated for Committee use.
}

The Desk must consider not only the policy directive, but also all the discussion at the preceding FOMC meeting, staff projections of financial and other economic conditions, and day-to-day developments in the financial markets. Each morning, before executing operations for the day, the Desk calls the Board of Governors and one district bank president who is a voting member of the FOMC. During this "morning call," if they believe the operations of the Desk are not in line with the intent expressed by the FOMC at the last meeting, the Board members or bank president may suggest changes in open market operations. However, the Desk's responsibility is to the whole Committee, not to any individual member; hence it is not required to follow the advice given on these "morning calls."

The Desk, for the most part, has interpreted the operating instructions contained in the directive in terms of short-term money market conditions. This has generally meant conducting open market operations between meetings of the FOMC to control the Federal funds rate and the level of member bank free reserves or net borrowed reserves ${ }_{2}{ }^{2}$ and shortterm interest rates such as the Treasury bill rate. A rise in the Federal funds rate or a decrease in the level of member bank free reserves indicates open market operations have exerted a tighter influence or allowed a "firming in money market conditions." If, between FOMC meetings, the Federal Funds rate and free reserves average approximately the same as over the period prior to the last meeting, this is taken as an indication that the Desk has operated so as to "maintain existing money market conditions."

\section{FOMC Decisions in 1969}

The major policy goal of the FOMC in 1969 was to conduct open market operations in a manner that would reduce the rate of expansion of total spending and hence ultimately result in a slowing in the rate of increase of prices. The stated policy goals in the directive remained essentially the same at each meeting:

... to foster financial conditions conducive to the reduction of inflationary pressures, with a view to encouraging a more sustainable rate of economic growth and attaining reasonable equilibrium in the country's balance of payments.

Inflation was the primary concern of the Committee, but at the same time they wanted to avoid a degree

\footnotetext{
2Member bank free reserves are equal to excess reserves of member banks less member bank borrowings from the Federal Reserve. If borrowings exceed excess reserves, as in 1969 , then this figure is negative, and is referred to as net borrowed reserves.
} 


\section{EXHIBIT I}

\section{FEDEAL OPEN MARKE COMMUTEF ECONOMU POMCY DURETUES}

\begin{tabular}{|c|c|c|c|}
\hline $\begin{array}{l}\text { Date of } \\
\text { FOMC } \\
\text { Meeting }\end{array}$ & Policy Consensus & Operating Instructions & Proviso Clause of Directive \\
\hline January 14 & $\begin{array}{l}\text { In this sifuation, it is the policy of the } \\
\text { Federal Open Market Committee to foster } \\
\text { financial conditions conducive to the reduction } \\
\text { of inflationary pressures with a view to en- } \\
\text { couraging a more sustainable rate of economic } \\
\text { growith and attaining reasonable equilibrium in } \\
\text { the country's batance of payments. }\end{array}$ & $\begin{array}{l}\text { To implement fhis policy, System open market opera- } \\
\text { tions until the next meeting of the Committee shall be } \\
\text { conducted with a view to maintaining the prevailing firm } \\
\text { conditions in money and short-term credit markets; }\end{array}$ & $\begin{array}{l}\text { provided, however, that operations shall be modified, } \\
\text { to the extent permilted by the forthcoming Treasury } \\
\text { refunding, if bank tredit expatsion appeats to be } \\
\text { deviating significantly from current projections. }\end{array}$ \\
\hline & $\begin{array}{l}\text { Dissents: } \\
\text { Mr. Morris }\end{array}$ & & \\
\hline February 4 & $\begin{array}{l}\text { No change } \\
\text { Dissents: } \\
\text { None }\end{array}$ & $\begin{array}{l}\text { System open market operations until the next meeting of } \\
\text { System actount of the current Treosury refunding, } \\
\text { the Committee shall be conducted with a yiew to maintain. } \\
\text { ing the prevailing firm conditions in money and shortaterm } \\
\text { credit markets; }\end{array}$ & $\begin{array}{l}\text { provided, however, that operations shall be modified, } \\
\text { to the extent permitted by the Treasury refunding, if } \\
\text { bank credit appears to be deviating significantly from } \\
\text { current projections. }\end{array}$ \\
\hline March 4 & $\begin{array}{l}\text { No change } \\
\text { Dissents: } \\
\text { None }\end{array}$ & $\begin{array}{l}\text {. System open makket operations until the next meeting } \\
\text { of the Committee shall be conducted with a view to main- } \\
\text { taining on balance about the prevaliling firm conditions in } \\
\text { money and short-ferm credit markets; }\end{array}$ & $\begin{array}{l}\text { provided, however, that operations shall be modified } \\
\text { if bank tredit appears to be deviating significantly } \\
\text { from current projections. }\end{array}$ \\
\hline April 1 & $\begin{array}{l}\text { No ehange } \\
\text { Dissents: } \\
\text { Mr. Coldwell } \\
\text { Mr. Maisel }\end{array}$ & $\begin{array}{l}\text { System open market operations until the next meeting } \\
\text { of the Commiltee shell be conducted with a view to main- } \\
\text { taining firm conditions in money and short-term credit } \\
\text { markets, taking account of the effects of other possible } \\
\text { monetary policy action; }\end{array}$ & $\begin{array}{l}\text { provided, however, that operations shall be madified } \\
\text { if bank credit appears to be deviating significantly } \\
\text { from current projections. }\end{array}$ \\
\hline April 29 & $\begin{array}{l}\text { No change } \\
\text { Dissents: } \\
\text { None }\end{array}$ & $\begin{array}{l}\text { while saking account of the forthcoming Treasury } \\
\text { refunding, System open market operations until the next } \\
\text { meeting of the Committee shall be conducted with a view } \\
\text { to maintaining the prevailing firm conditions in money } \\
\text { and short-term credit markets. }\end{array}$ & $\begin{array}{l}\text { provided, however, that operations shall be modiffed } \\
\text { if bank credit appears to be deviating significantly } \\
\text { from current projections. }\end{array}$ \\
\hline Moy 27 & $\begin{array}{l}\text { No thange } \\
\text { Dissents: } \\
\text { None }\end{array}$ & $\begin{array}{l}\text {. System open markel operafions until the next meeting } \\
\text { of the Committee shall be conducted with a view to main- } \\
\text { taining the prevailing pressure on money and short-ferm } \\
\text { credit markets; }\end{array}$ & $\begin{array}{l}\text { provided, however, that operations shall be modified } \\
\text { if bank sredit appears to be deviating significantly from } \\
\text { current projections. }\end{array}$ \\
\hline
\end{tabular}


June 24 change
Dissents:

Mr. Maisel
.. System open market operations until the next meeting of the Committee shall be conducted with a view to main taining the firm conditions currently prevailing in shortererm credi provided, however, that operations shall be modified if bank eredit appears to be deviating significantly from current propections or if unusual liquidity pressures should develop.

provided, however, that operations shall be modified, provided, however, that operations shall be modified to the exiens permitted by the Treasury refunding, if current projections. refunding, System open market operations shall be confirm conditions in money and shorl-term credit markets;

.. System open morket operations until the next meeting of the Committee shall be conducted with a view to main taining the prevaling firm conditions in morey and shortterm eredit markets:

provided, however, that operations shall be modifed if bank credit appears to be deviating significantly from current profections or if pressures arise in connection with foreign exchange developments or with bank regulatory changes. sustainable economic growth, instead of. more sustainable economic growth. The word "more" was dropped to aroid the implication that reduced rates of growth of real GNP might not be sustainable over the lang run.

$$
\begin{aligned}
& \text { Mr. Maisel } \\
& \text { Mr. Mitchel }
\end{aligned}
$$

September 9 No change

$$
\text { Dissents: }
$$

Mr. Moisel

Mr. Mitchel while taking accoun of the forthcoming Treasury re funding, System open markel operations until the next meeting of the Committee shall be conducted with a view to mointaining the prevaling frm conditions in money ond short-term credil markets,

provided, however, that operations shall be modified to the extent permitted by the Treasury refunding, if bank credit appears to be deviating significantly from current projection or if pressures arise in connection with foreign exchange developments or with bank regulatory changes.

$\begin{array}{cc}\text { October } 7 & \text { No change } \\ \text { Dissents: } & \text { System open market operations until the next meeting } \\ \text { Mr. Maisel } & \text { of the Committee shall be conducfed with a view to main- } \\ \text { laining the prevailing firm conditions in money and short- }\end{array}$
taining the prevaling firm conditions in money ond main term eredit markets.

provided, however, that operations shall be modified if bank credit appears to be deviating significantly from current projections. Wystem open market operations until the nexf meeling

October 28 No change

Dissents: of the Committee shall be canducted with a view to maintoining the prevaiting firm conditions in money and shortterm credis markets,

November 25 No change

Dissents:

None

System open market operations until the next meeting of the Committee shall be conducted with a view to maintrining the prevailing firm conditions in money and short. term credit markets;

December 16 No change
Dissents:

$$
\text { Dissents: }
$$

None

. System open market operations until the next meeting of the Commitfee shall be conducted with a view to maintaining the prevaliing firm conditions in the money markef; provided, however, that operations shall be modified if bonk credit appears to be deviating significantly from eurrent projections.

provided, however, that operations shall be modifled if bank credif appears to be deyiating significantly from current projections of if pressures arise in connection with possible bank regulatory chonges.

provided, however, that operations shals be modified if bank credit appears to be deviating significantly from current projections of if unesual liquidity pressures should develop.

$\begin{aligned} \text { SOURGE: Federal Open Market Commitee } & \text { Policy Record Entries, Curent }\end{aligned}$ 
of restriction that would precipitate a serious downturn in economic activity.

The decision to "tighten" monetary policy had come at the December 17, 1968 meeting of the FOMC. By that time it was apparent that such a move was necessary to reduce inflationary pressures. The available evidence convinced many members of the FOMC that the fiscal restraint embodied in the 10 per cent surtax and planned expenditure cuts could not sufficiently quell total demand in the face of the strong demand pressures in the economy,

Therefore, the FOMC instructed the Desk that "open market operations be conducted with a view to attaining firmer conditions in money and short-term credit markets, taking account of the effects of other possible monetary action." The "other monetary action" referred to an increase in the Federal Reserve discount rate from $51 / 4$ to $5 \frac{1}{2}$ per cent announced on December 17 and effective the day following the FOMC meeting. Previously, during the second half of 1968, the instruction had been simply to "maintain about the prevailing conditions" or to accommodate somewhat less firm conditions. ${ }^{3}$

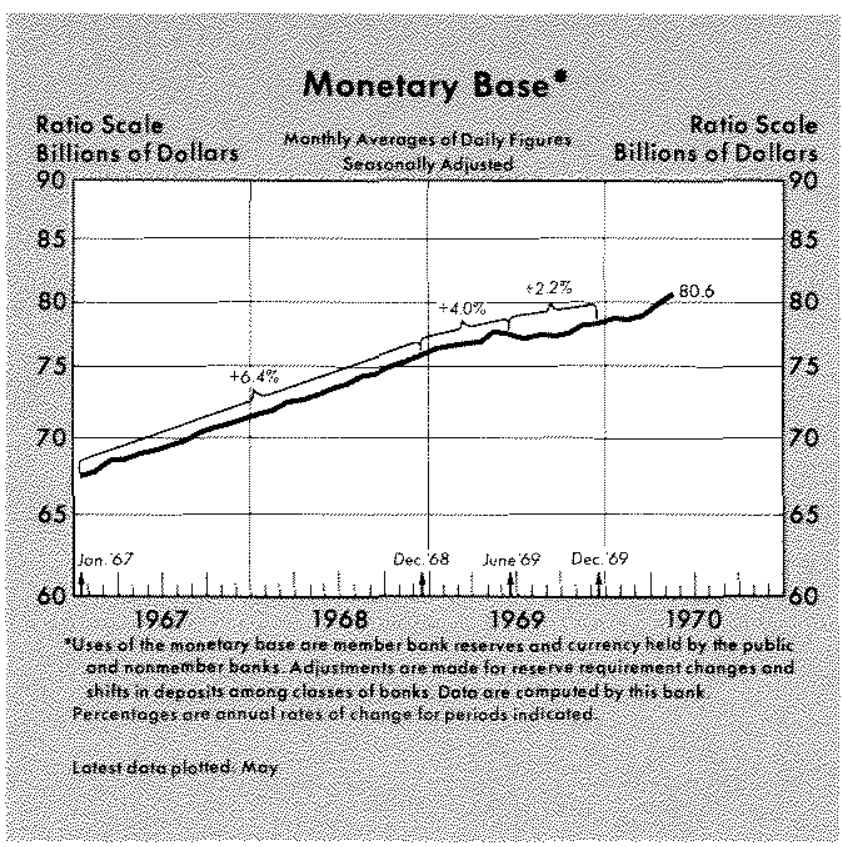

Although the operating instructions in terms of money market conditions contained in the directive remained almost unchanged throughout 1969 , the year may be divided into two periods using other measures of the degree of restraint such as the growth rate of the monetary base or bank reserves.

3See Jerry L. Jordan and Chartotte E. Ruebling, "Federal Open Market Committee Decisions in 1968 - A Year of Watchful Waiting," this Review (May 1969), pp. 6-15.
These variables indicate a move to restraint in the period from January through June and increased restraint from mid-year to the end of 1969.

\section{Januty Thongl Jane - Wone bo Restrath}

This period encompasses seven FOMC meetings. Referring to Exhibit $I$, the wording of the primary instructions in the second paragraph of the directive remained almost unchanged. The policy directive issued to the Desk was to:

... maintain the prevailing firm conditions in money and short-term credit markets.

According to the proviso clause, open market operations were to be altered only if:

... bank credit appears to be deviating significantly

from current projections.

During the first half of 1969 the continuing consensus of the FOMC appears to have been that "persistence of upward pressures on prices and wide. spread inflationary expectations" made it desirable to maintain monetary restraint. At the January 14 meeting, economic activity was projected to show a further slowing in the first half of 1969. Consumer spending was expected to continue to grow at a moderate rate, with higher social security taxes and retroactive payments on 1968 income taxes exercising a dampening influence. On the other hand, industrial production and payroll employment were continuing to rise rapidly in December 1968, and the unemployment rate was at a 3.3 per cent level in November and December. Further rapid increases in prices were expected.

At the February 4 and March 4 FOMC meetings the analysis of economic conditions was basically the same as at the mid-January meeting. Slower growth in real output and some easing in inflationary pressures were projected for the second half of 1969 . The members of the FOMC noted the continued downward trend in outstanding large-denomination certifi. cates of deposit and the moderation in the expansion of demand deposits. At the same time some concern was expressed over the growth of business loans and the growing use of nondeposit sources of funds by banks. ${ }^{4}$ The upward pressures on prices remained the primary concern of the Committee. The majority decision was for no change in the existing degree of monetary restraint.

4This concern was partly evidenced by the use of an adjusted bank credit proxy - daily averages of member bank deposits, adjusted to include changes in the daily average of U.S. bank liabilities to foreign branches. 
Some members urged caution in applying monetary restraint at the first three meetings of the year. At the January meeting Mr. Morris dissented on the grounds that the directive could be consistent with an unduly restrictive monetary policy. Comments at the following meetings on the proviso clause indicated the delicate balance under which open market operations were to be conducted. The Committee agreed that the proviso clause should be invoked in the direction of firming only if bank credit appeared to be growing at more than a moderate rate. They also cautioned that the proviso clause should not be allowed to give the impression that the basic stance of monetary policy had been relaxed.

Projections of GNP for the April I FOMC meeting were revised upward. Expansion of real GNP in the first quarter appeared to have moderated less than was projected earlier. The upward revision in the projection of future economic activity was based to a large extent on a Department of Commerce-SEC survey taken in early February. This survey indicated that business planned a 14 per cent increase in new plant and equipment spending in 1969 compared to 1968. Also, retail sales data indicated that consumer spending had not moderated to the extent projected earlier. Nonfarm employment had continued to expand in February, unemployment remained at a 3.3 per cent level, and average hourly earnings of production workers continued to rise.

The consensus of the FOMC at the April 1 meet ing was that "some further monetary policy action was called for at this time in the light of the greaterthan-expected pace of the economic expansion and the continuation of pervasive inflationary pressures and expectations." Prior to the meeting, the boards of directors of eight Reserve Banks had approved increases in the discount rate, and submitted these increases to the Board of Governors for approval. At this meeting discussion was also directed to the question of the desirability of an increase in member bank reserve requirements. Generally, the members of the Committee agreed on the desirability of an increase in the discount rate. However, there was some difference of opinion on the desirability of raising reserve requirements.

There were two dissents from the majority view at the early April meeting. Mr. Coldwell, president of the Dallas Federal Reserve Bank, expressed the view that greater monetary restraint was called for in the light of current conditions. Governor Maisel dissented from the majority opinion for the opposite reason. Govemor Maisel's opinion was summarized as follows:

\begin{abstract}
... insolar as the Committee's action reflected a desire to affect the prevailing inflationary psychology directly, it represented a shift from the Committee's proper concern with flows of credit and money to an improper target not readily susceptible to such inflence. He particularly objected to the directive as adopted because he thought that operations under it were likely to depress flows of the monetary aggregates to rates below those that seemed to him to be desirable and maintainable for a considerable period, and that such operations would thus be inconsistent with the gradualist approach to the ultimate objective of price stability that he favored.
\end{abstract}

Two days later the Board of Governors announced an increase in the discount rate by district Reserve Banks and raised the reserve requirements on member bank demand deposits. By April 8, all Reserve Banks had raised their discount rate from $5^{1 / 2}$ per cent to 6 per cent. Effective April 17, member bank reserve requirements on net demand deposits were raised by one-half of one percentage point.

At the FOMC meeting held in late April, the members of the Committee were presented with preliminary estimates which indicated real GNP had expanded in the first quarter at only a slightly reduced rate. Staff projections for the second quarter suggested that GNP would grow at approximately the same rate as in the first quarter. A further slowing in real GNP in the second half of the year was projected based on the lagged effects of monetary restraint and a continued restrictive fiscal policy. However, projections for the second half of the year still pointed to continued upward pressures on prices.

At this meeting, although some members questioned whether greater monetary restraint should not be exercised, the consensus was against a further move to more restraint. The majority view was based on the expected lagged effects of the previous monetary restraint on economic activity later in the year and the forthcoming Treasury financing. The FOMC decided that open market operations should be directed to "maintaining the firmer conditions in money and short-term credit markets that had been achieved." The proviso clause directed the Desk to alter operations, insofar as Treasury financing permitted, if bank credit appeared to be deviating significantly from current projections.

The analysis of economic conditions presented at the May 27 meeting indicated a further slight moderation in economic activity. However, little evidence of any abatement in inflationary pressures was pre- 
sented; and prices were projected to continue rising at a rapid pace. Financial markets were expected to come under heavy pressures in June as a result of the near record volume of corporate income tax payments due at mid-June.

Despite these indications of some slowing in economic activity and possible pressures in financial markets in June, the FOMC decided that in view of the persistence of strong inflationary pressures and expectations, a relaxation of the existing degree of monetary restraint would not be appropriate at this time. Special note was made that in recent months banks had increasingly drawn on nondeposit sources of funds other than Eurodollars, and these sources of funds were not reflected in the bank credit proxy as currently calculated. "Some members, taking this factor into account, argued that the change in the adjusted bank credit proxy be kept in the lower end of its projected range of zero to 5 per cent from May to June.

The Directive and Money Market ConditionsJudging the influence of open market operations in terms of money market indicators - the Federal funds rate and free reserves - the net effect of open market operations resulted in progressively tighter money market conditions through the end of May. Although the directive issued at each meeting expressed an intent on the part of the Committee to "maintain prevailing firm conditions in the money and shortterm credit markets," the Federal funds rate and net borrowed reserves increased between each meeting in the first five months of 1969. During part of this period the decision to permit tighter money market conditions was influenced by moderately lower Treasury bill yields. For example, at the May 27 meeting it was reported that since the previous meeting the System had not fully offset reserve drains, in light of the tendency for bill yields to move below the lower end of their recent ranges.

Table I presents averages of the Federal funds rate and net borrowed reserves between each FOMC meeting. The average level of the Federal funds rate rose from 6.21 per cent in the three weeks ending January 11 , to an average of 6.80 per cent between the March 4 and April 1 meeting, then in-

\footnotetext{
${ }^{5}$ For example nondeposit funds were obtained by sales of commercial paper by bank holding companies and sales of loan participations to nonbank customers under agreements to repurchase.
}

creased steadily to an average of 8.31 per cent by the May 27 FOMC meeting. Average net borrowed reserves rose from $\$ 402$ million at the beginning of the year to $\$ 725$ million prior to the April 1 meeting, and then to an average of $\$ 1,116$ million prior to the May 27 FOMC meeting.

The rise in the level of net borrowed reserves from the end of December 1968 to the end of May 1969 reflected primarily a sharp increase in the level of member bank borrowings from the Federal Reserve Banks. The average level of member bank borrowings rose from $\$ 841$ million in the four weeks ending January 15 , to $\$ 1,359$ million in the four weeks end. ing May 28, 1969. According to one view the rising level of member bank borrowings reflected primarily the response of the banks to the increasing spread between the discount rate and yields on short-term business loans.

The cost to member banks of borrowing from Federal Reserve Banks remained fixed at 5.5 per cent until April 4. The average yield on short-term business loans by commercial banks rose from 6.61 per cent in November 1968 to 7.32 per cent in February 1969. In early April the discount rate was raised to 6 per cent. However, yields on short-term business loans rose to 7.86 in May 1969, and beginning in late May, Treasury bill yields began to rise to higher levels. A further indication of the rising yields available to banks on short-term business loans was the prime rate, which banks raised from $6^{3 / 4}$ per cent in December 1968 to $7 \frac{1}{2}$ per cent on March 17 and then to $8^{\mathrm{t} / 2}$ per cent on June 9 .

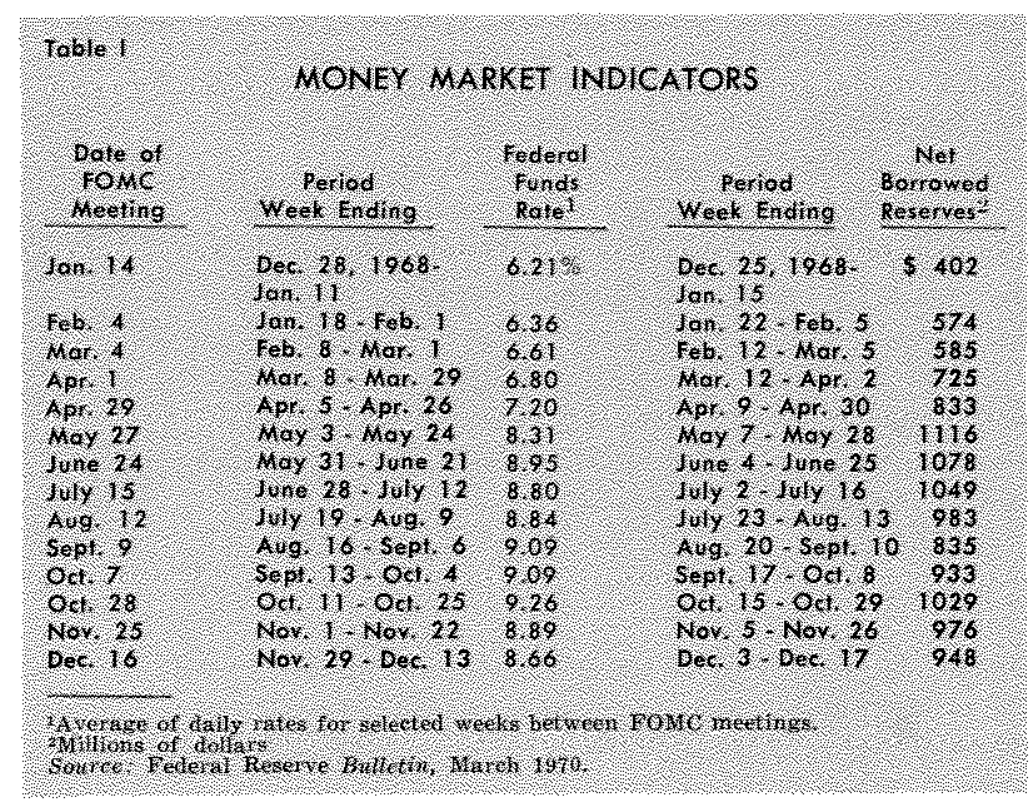




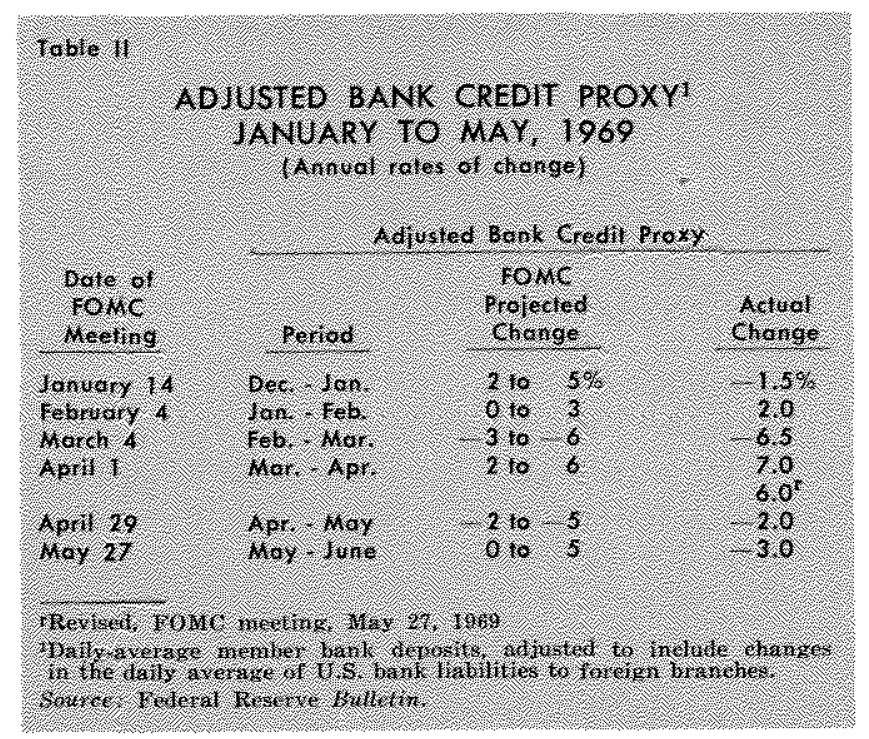

Proviso Clause - An analysis of open-market operations must also include a consideration of the proviso clause. Under the proviso clause, the Desk during the first half of 1969 was to alter its operations if:

... bank credit appears to be deviating significantly from current projections.

Table II presents the range projected for the adjusted bank credit proxy at each of the first six FOMC meetings in 1969, and also the actual change in the adjusted bank credit proxy for these periods. These data are taken from the "Records of Policy Actions" published in the Federal Reserve Bulletin and the Annual Report. For example, at the March 4 meeting the current projection was that the adjusted credit proxy would decline at an annual rate of 3 to 6 per cent from February to March. The actual decline of the adjusted credit proxy from February to March was later reported to be at a 6.5 per cent annual rate.

Examining Table II, the actual rate of change of the adjusted credit proxy was below the range projected for January, in the middle of the range projected for February, and below the range projected for March. Deviations of the bank credit proxy during most of this three-month period appear to have been in the direction of a greater slowing in bank credit than had been projected. During this period the Federal funds rate rose from 6.21 per cent to 6.80 per cent, and net borrowed reserves rose from $\$ 402$ million to $\$ 725$ million.

One explanation given in the Annual Report of this increasing tightness in money market conditions was that the Federal Reserve System was reluctant to permit any indication of easing in monetary policy.
According to the Desk Manager's Report on Operations of the Open Market Account:

. . during March, the interpretation of the bank credit proxy in light of proviso clause of the directive was unusually difficult.

On the surface, the levels projected might have suggested implementation of the proviso clause on the side of slightly less restraint. But several factors argued against such implementation. First there was considerable market belief that the System would not persevere in its policy of restraint, so such a move would have risked being interpreted as a greater relaxation of monetary restraint than in" tended - particularly in view of the decline in Treasury bill rates after early March. Second, there was growing evidence that banks might be expanding credit in ways not measured by the proxy. And finally, the estimates for April pointed to a probable rise in the proxy, reversing the March decline. In light of all these circumstances, the proviso clause was not implemented. ${ }^{6}$

In April the credit proxy expanded at an estimated 7 per cent rate, above the upper end of the range

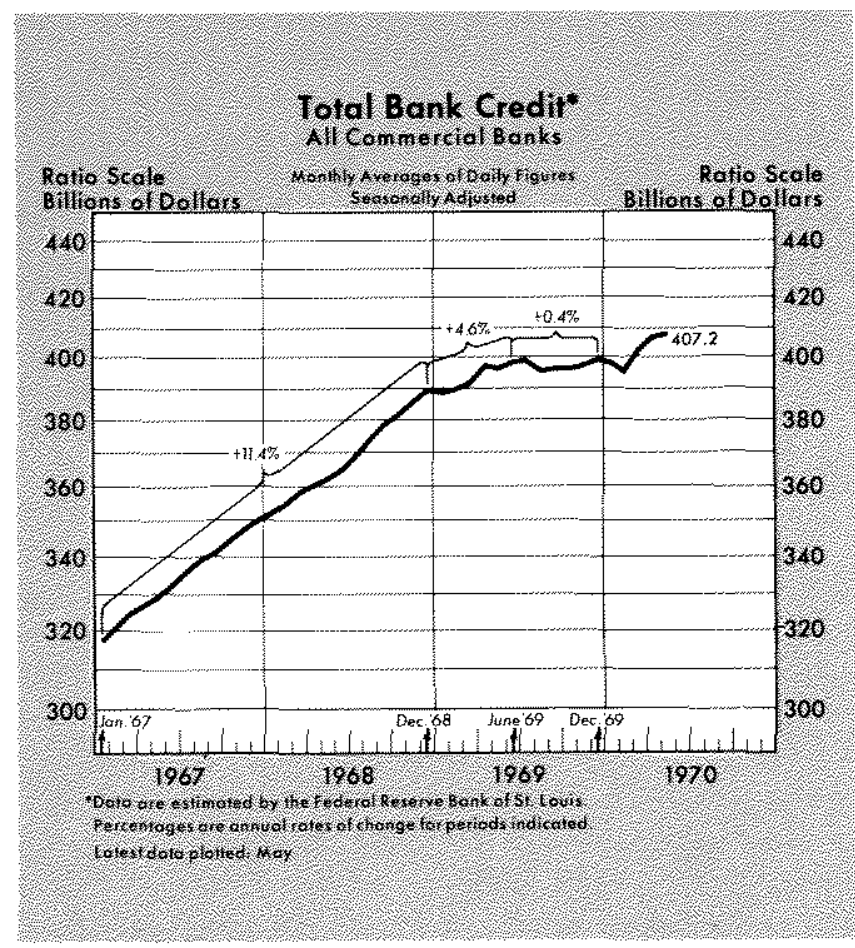

projected at the April 1 meeting. As reported in the April 29 Policy Record, "open market operations were modified in the direction of greater firmness as the period progressed, when it became increasingly clear that bank credit was expanding at a pace significantly in excess of the range projected at the previous meeting."

${ }^{6}$ Federal Reserve Board of Governors, Annual Report, 1969, pp. $219-220$. 
At the April 29 FOMC meeting, staff projections suggested a marked reversal in May of the rate of growth of bank credit, a rate of decline of 2 to 5 per cent. Open market operations appear to have been directed to maintaining money market conditions that would ensure the reversal in the growth rate of the credit proxy. The credit proxy declined at an annual rate of 2 per cent, at the upper end of the projected range, between the meetings at the end of April and end of May. During the same period the average level of the Federal funds rate rose to 8.31 per cent and net borrowed reserves averaged $\$ 1,1,16$ million.

According to the Report of the Desk Manager, open market operations were partly conditioned by:

... the tenacity of doubts concerning the resolution of the System to hold fast to a policy of stern restraint. The net result of System operations in the April-May interval was to make amply clear that the Federal Reserve was serious about monetary restraint $^{\top}$

At the late May meeting the range projected for the adjusted credit proxy in June was a 0 to 5 per cent annual rate of increase. As discussed earlier, due to the growing use by banks of nondeposit sources of funds, some members of the FOMC urged that the growth rate of the adjusted credit proxy be kept closer to zero than 5 per cent. In June the result of open market operations was somewhat firmer money market conditions. The adjusted credit proxy declined at a 3 per cent annual rate in June, considerably below the lower end of its projected range.

Summary - During the first half of 1969 the wording of the published directive remained about the same at each FOMC meeting. However, the actual implementation of open market operations resulted in progressively tighter money market conditions. When the annual rate of change of the adjusted credit proxy was in the lower end or below the projected range, the Desk did not appear to have altered operations to ease money market conditions. When the credit proxy increased at a more rapid rate than projected, as in April, the Desk altered open market operations toward considerably firmer money market conditions as measured by the Federal funds rate and net borrowed reserves. The maintenance of prevailing money and short-term credit market conditions from one FOMC meeting to the next would have required considerably larger purchases of Gov-

TFederal Reserve Board of Governors, Annual Report, 1969, p. 221.

Page 16 emment securities to keep the Federal funds rate and net borrowed reserves at a relatively constant average level.

The open market actions of the Desk, which resulted in progressively tighter money market conditions and a growth rate of the adjusted credit proxy in the lower end of its projected growth range, appear to have been in line with the consensus of the members of the FOMC. During this period there were only two dissents by FOMC members commenting on the progressive tightening of monetary policy as indicated by money market conditions and monetary aggregates. As discussed earlier, these were the dissent of Mr. Morris at the January 14 meeting and Governor Maisel's statement at the April 1 meeting.

\section{Why wo Downber - w meased

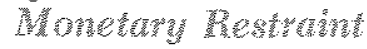

The expansionary effects of monetary influences on the future growth of economic activity were further markedly reduced in the second half of 1969 , as indicated by monetary aggregates and market interest rates. The money stock showed almost no increase on average from June to December 1969, compared to a 4.4 per cent rate of increase from December 1968 to June 1969. Likewise, bank credit on balance did not increase in the last half of 1969 , compared to a 4.6 per cent rate of increase over the first six months. In the last half of the year market interest rates continued to increase. The Treasury bill rate had re-

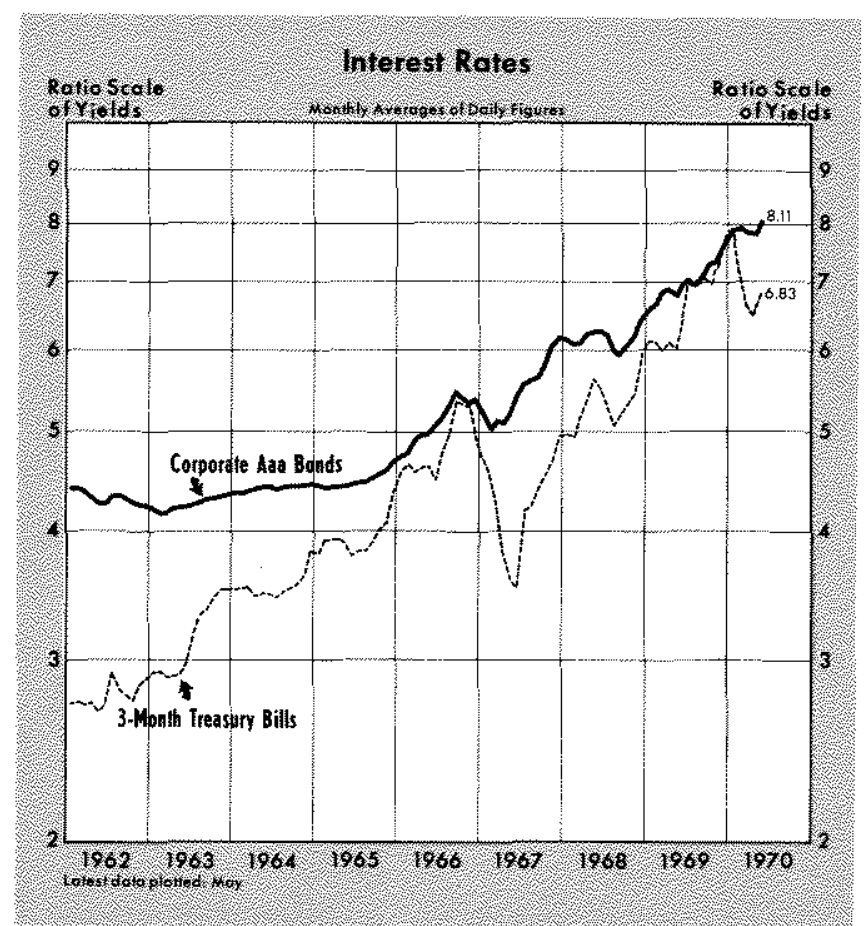


mained about constant over the first half of the year. Then, from an average of 6.01 per cent in the period before the May 27 FOMC meeting the Treasury bill rate rose to an average to 7.63 per cent prior to the December 16 meeting.

At the FOMC meetings in late June and mid-July, the members of the Committee were presented with GNP forecasts that suggested further slowing in real output growth in the second half of the year, reaching a relatively low growth rate in the fourth quarter. Staff projections indicated continued restraint in Federal expenditures, a continued decline in residential construction, a moderate rate of consumer spending, and a marked deceleration in the growth of capital spending by business after mid-year.

At these two meetings there was further discussion about the increased use by banks of nondeposit sources of funds and some consideration of possible means of limiting banks' access to this type of funds. Discussion was also directed to Eurodollar borrowings by banks and outflows of U.S. funds to the Eurodollar market along with their effects on the U.S. balance of payments. Consideration was also given to the desirability of increasing discount rates and raising Regulation $Q$ ceiling rates on large-denomination CD's.

The consensus of the members of the FOMC was that, although there were some preliminary signs of slowing in the rate of growth of real product, inflationary pressures and expectations remained strong and hence argued against any move to a lesser degree of monetary restraint. At both of these meetings, some members of the FOMC expressed a belief that, in the light of the slow response of prices to current policy, any doubts arising from the conduct of open market actions should be resolved in the direction of further firming of money market conditions. However, the majority of the membership of the Committee agreed that open market policy should remain unchanged. At the June 24 meeting, some members noted the strains evident in financial markets and the possibility of unusual liquidity pressures. At the July 15 meeting the members agreed that the forthcoming Treasury refunding militated against any appreciable change in open market policy.

At the June 24 meeting Governor Maisel dissented from the majority view. In his dissent, as summarized in the Policy Record, Governor Maisel noted that, on balance, conditions in money and short-term credit markets were now considerably firmer than at the end of April, while the monetary aggregates had been declining:
He was concemed that further tightening to an undesirable degree might occur under the directive favored by the majority today, since the language of the second paragraph was similar to that of the directives the Committee had issued on April 29 and May 27 .... In his judgment, moderate positive rates of growth in bank credit were appropriate under current circumstances, and he thought it would be desirable for the Committee to act now to bring about a transition to maintainable financial conditions. Accordingly, he preferred a directive calling for maintenance of the money and short-term credit market conditions that had prevailed on the average in the second quarter rather than the tighter conditions currently prevailing.

On July 24 the Board of Governors amended Regulation $D$ on member bank deposits subject to reserve requirements. This action made certain bank deposit liabilities arising out of Eurodollar transactions subject to reserve requirements. At the August 12 FOMC meeting it was estimated that this action would raise required reserves of member banks by $\$ 450$ million in the statement week ending August 20. This action and the expectations by banks that the Federal Reserve Board would soon implement other proposed amendments to Regulation D were expected to reduce banks demand for nondeposit funds. Other matters considered by the Committee included the recent French devaluation of the franc, and the expectation that the Treasury would raise about $\$ 1.5$ to $\$ 2$ billion of new cash later in August.

The consensus of the members of the Committee was that, due to the continued inflationary pressures in the economy, it was necessary to maintain the existing degree of monetary restraint. However, the majority agreed that any tendencies toward firmer money market conditions resulting from recent regun latory actions by the Board of Governors or foreign exchange developments should be resisted by open market operations.

At this meeting Governor Mitchell joined Governor Maisel in dissenting from the majority opinion. In their opinion monetary policy had become more and more restrictive. To guard against what they viewed as an undesirable further tightening as reflected in a further downward trend of the monetary aggregates, they favored a directive calling for modification of open market operations if such decline in monetary aggregates did in fact occur.

Information on economic activity available at the September and early October meetings provided some further signs of easing in total demand for output. Staff projections were for continued slowing in growth of real output through the second quarter 
of 1970. The available data, however, continued to indicated pervasive price increases. Also, at the October 7 meeting it was noted that fiscal policy was likely to become less restrictive in early 1970.

Based on their view that there were continued persistent inflationary pressures and expectations in the economy, and the possibility that fiscal policy would become less restrictive in early 1970 , the majority of the FOMC voted at both meetings that open market operations should be directed to maintaining the existing firm conditions in money and short-term credit markets. At both meetings several members emphasized the desirability of avoiding any firming in policy.

Governors Mitchell and Maisel, at the September 9 meeting, again voiced their dissent from the majority opinion. They expressed the belief that:

... in measuring the degree of monetary firmness or restraint the Committee should give more weight to movements in key monetary aggregates - such as the money stock, private demand deposits, total and nonborrowed reserves, and bank credit - and in longer-term interest rates. In their judgment, the fact that the monetary aggregates had been declining and longer-term interest rates had been rising in recent weeks indicated that restraint had been steadily increasing, even though money market conditions had been relatively stable. They favored maintaining the overall posture of restraint measured in terms of such aggregates and interest rates, and permitting more flexibility in money market conditions in order to do so.

Governor Maisel also dissented from the majority decision at the October 7 meeting, noting that:

. . . interest rates on all types of market securities had risen substantially on balance in the period since late April, and that during this period the Committee's directives - like that favored by the majority today - had called for maintenance of prevailing firm conditions in money and short-term credit markets. He also noted that the behavior of key monetary aggregates, including member bank reserves, the money stock, and bank credit, had been considerably weaker in the third quarter-either declining more rapidly or rising more slowly - than in the first half of the year; and that sharp declines in the aggregates were projected for October if prevailing money market conditions were maintained.

Repeating his views expressed at previous meetings, Governor Maisel stated his belief that more flexibility should be permitted in money market conditions, in order to maintain but not intensify the present degree of monetary restraint measured in terms of key aggregates and interest rates.
At the last three FOMC meetings in 1969 , evidence of the restrictive effects of monetary restraint on the real sector increased. At the October 28 meeting, key economic indicators still provided a mixed picture of the direction of economic activity. Industrial production declined in September for the second month in a row, the unemployment rate rose to 4 per cent from 3.5 per cent in August, retail sales adjusted for price increases were below a year earlier, and there was evidence of considerable slowing in the growth of personal income. On the other hand, new orders of manufacturers for durable goods showed a widespread increase in September, and wholesale prices of industrial commodities were increasing more rapidly than in the second quarter.

By the December 16 FOMC meeting the signs of slowing in economic activity were much more widespread. Industrial production declined in November for the fourth straight month. Most measures of labor market conditions indicated some easing in the demand for labor, and retail sales in real terms continued at a level below a year earlier. Staff projections were for a halt in the growth of real GNP in the fourth quarter and little or no rise in the first half of 1970 .

During October short-term and long-term interest rates had declined sharply. This decline, however, represented only a short-run reaction to announcements of possible improvements in peace negotiations on the Vietnam War and the publication of the 4 per cent unemployment rate for September. Beginning in late October the trend of market interest rates was reversed. Through the remainder of the year both long-term and short-term rates rose rapidly.

There was some discussion by the members of the Committee at the last meetings in 1969 over the renewed rapid rises in interest rates. At the last three meetings several members expressed the view that any tendencies toward lower market interest rates should not be offset by open market operations.

Concern was expressed at the November 25 meeting about the possible impact on financial markets of the October 29 announcement by the Board of Gov. ernors that it was considering amendments to Regulation $\mathrm{D}$ (reserve requirements) and Regulation $Q$ which would affect certain types of nondeposit funds of commercial banks. This concern was expressed in the proviso clause for the November 25 directive instructing the Desk to alter operations:

... if pressures arise in connection with possible bank regulatory changes. 
The Committee also discussed the possible effects of these interest rate developments on savings institutions, which were restricted in the level of interest rates they could pay depositors. The members noted there were large outflows from savings institutions following the September dividend period, and the possibility of a large amount of withdrawals following the end of the year dividend period was taken into consideration.

The FOMC's concern with possible liquidity pressures in financial markets was expressed in the proviso clause of the December 16 directive instructing the Desk to alter operations:

... if unusual liquidity pressures should develop.

Despite the mounting evidence of a developing slowdown in economic activity, the majority of the Committee decided at each of the last three meetings in 1969 that it would not be appropriate to relax the existing degree of monetary restraint. This decision appears to have been based primarily on the lack of any evidence of slowing in the increase of prices, and the view that inflationary expectations still remained firmly entrenched.

The Directive and Money Market Conditions - In the last half of 1969 , as over the first half, the directive repeatedly expressed a desire by the majority of the FOMC to have open market operations conducted to "maintain the prevaling firm conditions in money and short-term credit markets." Table I presents the

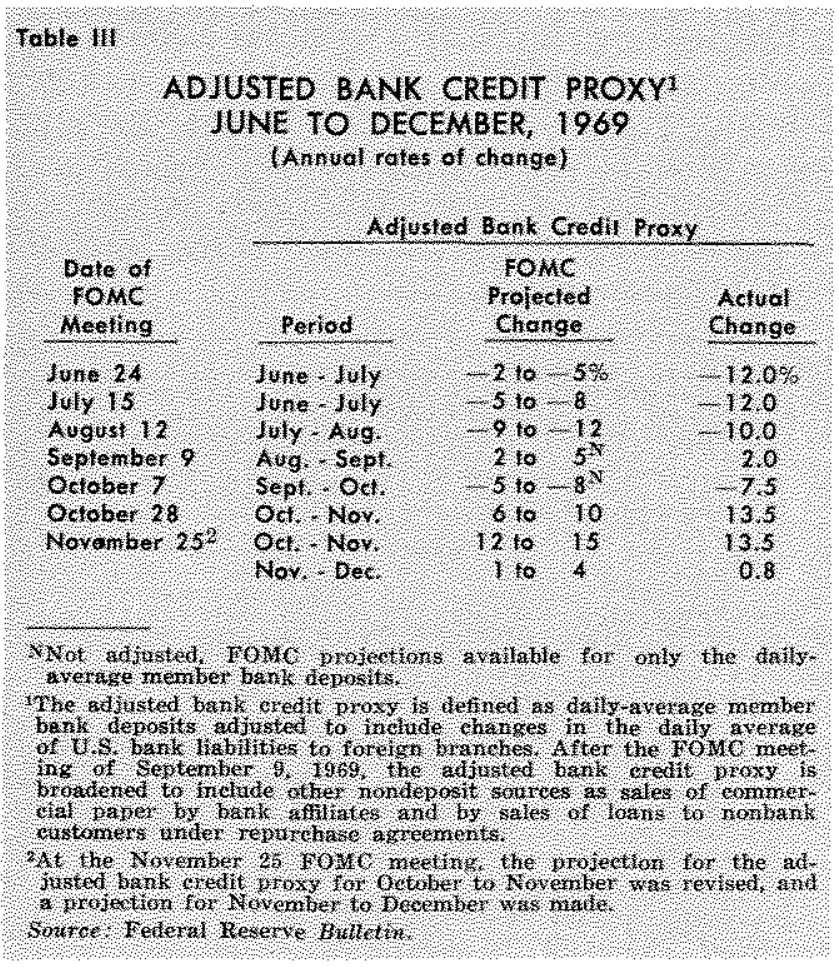

average level of net borrowed reserves and the Federal funds rate. Over the last half of 1969 , using these measures of money market conditions, the implementation of open market operations by the Desk resulted in approximately the same prevailing money market conditions. The Federal funds rate, on average, moved in approximately an 8.6 to 9.2 per cent range, and net borrowed reserves averaged in the range of $\$ 900$ to $\$ 1,000$ million.

Table III presents the projections for the bank credit proxy and the actual rates of change of the credit proxy. During most of this period the credit proxy was held in the lower end of its projected range.

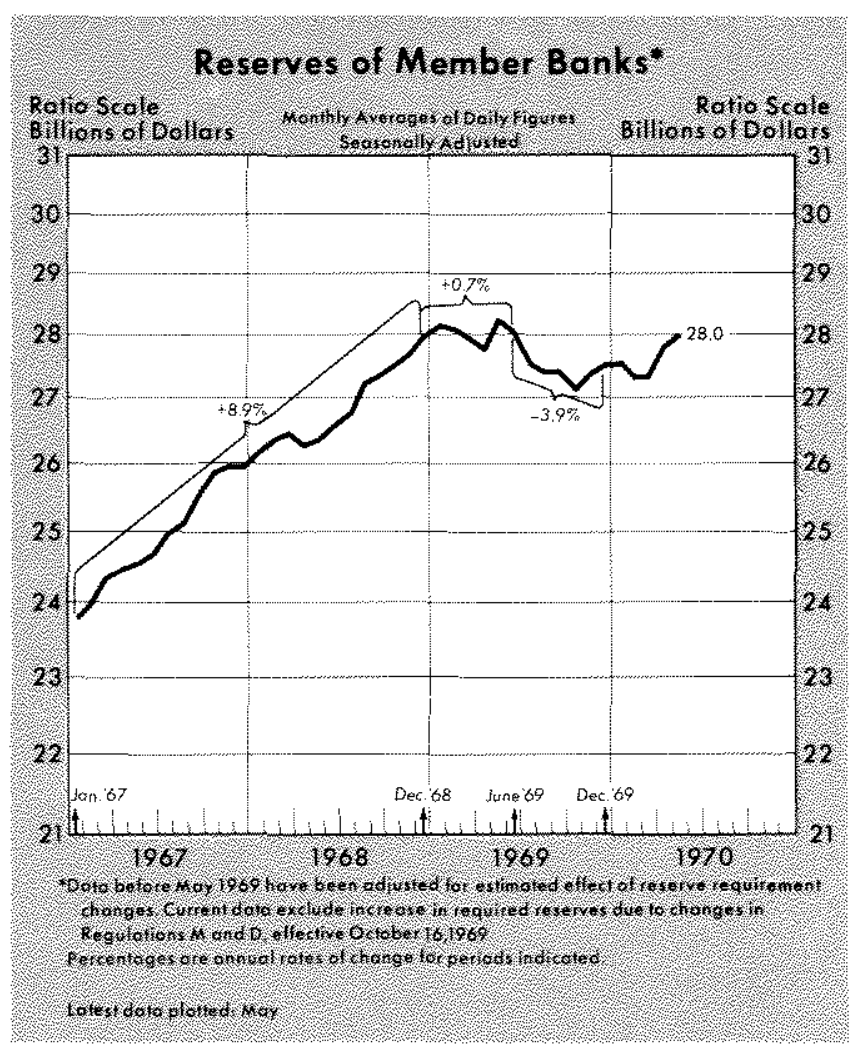

Other Measures of Restraint - In the second half of 1969 open market operations resulted in approximately the same firmness in money market conditions from one FOMC meeting to the next. However, other measures of the degree of restraint being exerted on the growth of the money stock and bank credit, such as member bank reserves and the monetary base, indicated considerably increased restraint.

From June to December total reserves declined at a 4 per cent annual rate, compared to a 0.7 per cent rate of increase from December 1968 to June 1969. The monetary base grew at a 2 per cent rate over the last six months of 1969 , only one-half as rapidly as during the first half of the year. From June to October 
growth of these key aggregates was sharply restricted. During this period the monetary base grew at only a 0.8 per cent rate and total reserves declined at a 9.5 per cent annual rate.

Over the first half of 1969 progressively tighter money market conditions, as measured by the Federal funds rate and net borrowed reserves, were coincident with decreases in the growth rates of the monetary base and reserves. In the second half of the year, relatively constant money market conditions were maintained, but the growth rates of the monetary base and reserves showed further sharp declines. The growth rates of money and bank credit followed the movements of the monetary base and reserves, declining further in the second half of 1969.

\section{Summary and Conclusions}

In 1969 the dominant concern of the FOMC reported in the records of policy actions was with inflationary pressures and inflationary expectations. The major policy goal of the Committee was to conduct open market operations so that the effect of monetary influences on the economy would be restrictive. During 1969 the net effect of monetary influences on the economy was substantially reduced. A reading of the directives issued by the FOMC does not give an adequate picture of the degree of restraint apparently desired by the members of the FOMC. Throughout the year the wording of the major clause of the directive was almost unaltered:

System open market operations until the next meeting of the Committee shall be conducted with a view to maintaining the prevalling firm conditions in money and short-term credit markets.

However, this article has pointed out that through the first half of 1969 , money market conditions as measured by the average levels of the Federal funds rate and net borrowed reserves became progressively tighter. This progressive firming in money market conditions appears to have been what the majority of the voting membership of the FOMC desired.

In the second half of the year, although the measures of money market conditions used in this article remained about constant, other measures of policy such as the monetary base and member bank reserves indicated that open market operations were exercising markedly greater restraint on the growth of money and bank credit. This distinction was pointed out in several dissents by Governors Maisel and Mitchell.

Published records suggest that the majority of the members of the FOMC were unwilling to move to an easier open market policy until they could see visible evidence of a reduction in the rate of price increases and until they were assured that expectations of rising prices had been broken. Such evidence did not materialize in 1969. These conditions tend to imply that, by voting to maintain existing money market conditions, the majority of the membership of the Committee desired monetary policy in the second half of the year to exercise an even more restrictive influence on future economic activity than in the first half of the year.

Because of the lagged effect of changes in the growth rate of the monetary aggregates on real economic activity, the full impact of the sharp reduction in the growth rates of money and bank credit on real output and employment did not appear until the first half of 1970 . Whether the restrictive monetary policy of 1969 will in fact reduce the rate of price increases and reduce inflationary expectations depends upon whether the rate of increase of money is held to a moderate rate during 1970 .

This article is available as Reprint No. 57. 